\title{
RISK ASSESSMENT OF UTERINE MICROORGANISM IN POSTPARTUM DAIRY COWS SALAH EDIN CITY
}

\author{
HALLA MAHMMED MAJEED \\ Dept. of Microbiology, College of Veterinary Medicine, Tikrit University, Tikrit-Salahaldin- Iraq
}

Received: 27 December 2017;

Accepted: 18 January 2018

\begin{abstract}
Objectives:- The research have been done to investigate risk assessment of uterine causative agent during postpartum cattle and record incidence of uterine contamination in cattle during the period from 1/1/2015 to $31 / 12 / 2015$.

Materials and Methods:- Diagnosis of the cases have been done by using a prepared questionnaire, Clinical evaluation, enzyme-Linked Immune sorbent assay (ELISA), culture media, Grams stains, biochemical test and Lacto phenol cotton blue.

Results:- The results showed that a total of 120 specimens were collect along three months after birth. The bacterial diseases are the most prevalent one $86.7 \%$ then the viral diseases $21.7 \%$ and finally fungi diseases were $8.33 \%$.

Conclusion: The Study has been revealed risk of uterine causative agent during postpartum cattle.
\end{abstract}

Key words: Risk, assessment, uterine, contamination, postpartum, birthing, Cattle.

\section{BACK GROUND}

Cattle cervix and uterus sterilized prior to calving provide a wall against pathogens attack for the duration of conception (Sheldon and Dobson, 2004).

After birth, uterus may possibly grow to be contaminated due to presence of contagious or noncontagious microbes. Numerous causative agents frequent may present after births (Erin et al., 2005).

Cattles uterus infected-during postpartum time usually be poorer pregnant rate following. Elevated proportion of bacteria present in uterus during the first two weeks after birth possibly consider as infections. Pathogenic microorganisms keep on a few cows cause uterine infection via disturb uterine physiology followed by sub-fertility in special cattle (Opsomer et al., 1996).

Bacterial contamination is the majority essential diverse causes of endometeritis. Such state may possibly cause cervicitis or endometritis with different degree, which lead to death of embryo and duplicate breeding trouble (Foldi et al., 2006 and Gilbert et al., 2005).

Corresponding author: Dr. HALLA MAHMMED MAJEED E-mail address: m.hala17@yahoo.com

Present address: Dept. of Microbiology, College of Veterinary Medicine, Tikrit University, Tikrit-Salahaldin- Iraq
Bacterial infection in reproductive tract generate infertility and troubles uterine and ovarian job. Many of the mechanisms that recognition of microorganism pathogens include innate immune system (Akira et al., 2006). These mechanisms not only important for classic immune cells but also marked in the endometrial and ovarian cells of mammals (Herath et al., 2009).

Uterine diseases metritis and endometritis, is define as acute diseases produce by microbial infection of the uterus that happening within the first 20 DIM (Sheldon et al., 2006) without systemic signs of disease. Current study also found that 2 free situations can effect resulting reproductive functioning: 1) phenomenon purulent vaginal discharge. 2) presence of high number of inflammatory cells in the endometrium (Dubuc et al., 2010). Retained placenta (RP) regard as uterine disease.

The research have been done to investigate risk assessment of uterine causative agent during postpartum cattle and record incidence of uterine contamination in cattle.

\section{METHODOLOGY}

\section{Study design:-}

The research was carried out during the period $1 / 1 / 2015$ to $31 / 12 / 2015$ in central research Laboratory. 120 Serum and uterine discharge samples from the same animals were collected. The cattle with uterine infection were from different region of Tikirt city. 
Uterine discharge was used for causative agents isolation and serum specimen was stored at $-20^{\circ} \mathrm{C}$ for serological tests.

A questionnaire was arranged and use to evidence information about age at delivery, kind, similarity, present physiological condition and genital act, new chief scientific disease, previous birth history, nature of birth, vaccination time and nature of inseminate.

\section{Clinical check}

Before collection of specimens, all cattle must be checked clinically. Body condition, location, crowdness, respiratory tract and pulse rate, and temperature. Finally, rectal palpation were done.

\section{Specimen assembly:-}

Prior to collection of specimens, perineal region are washed with freshwater and potassium perminganate solution. Left hand rectal palpation make up accumulate samples via use AI tube.

\section{Isolation of microorganisms:}

For the development of aerobic bacterial the specimens were culture on media for isolated bacteria and incubated at $37^{\circ} \mathrm{C}$ for 48 hours, Sabouraud dextrose agar contain choloramphenicol $0.05 \mathrm{gm} / \mathrm{ml}$ and incubated at $30^{\circ} \mathrm{C}$ for $2-5$ day for isolatation of fungi. Blood samples $(5 \mathrm{ml})$ were obtained from each cattle by Jugular vein-puncture. Serum haptoglobin concentration were assayed according to Levinson and Jawetz (1994). Commercial indirect Elisa kits (Svanova Bio AB Uppsala/Sweden) were used for BVDV and IBRV antibodies in samples according to manufacturer instruction.

\section{Cultural characteristic:}

The growth microorganism recognized by colony morphology, staining, hemolytic pattern, selective media, Lacto phenol cotton blue and biochemical tests.

\section{RESULTS}

Different types of genital disease or else disorder for the period of sample collected works. The four types was regard asas 'uterine disease' due to occurrence secretion sum of 120 cows chosen the study. The frequency uterine contagion was establish120 cows (Table1).

Table 1: Prevalence of genital diseases or disorder $(n=120)$

\begin{tabular}{llcl}
\hline & Diseases & Number & $\%$ \\
\hline $1-$ & endometritis & 50 & 41.7 \\
\hline $2-$ & pyometra & 30 & 25 \\
\hline $3-$ & cervicitis & 30 & 25 \\
\hline $4-$ & abortion & 10 & 8.3 \\
\hline & & 120 & 100 \\
\hline
\end{tabular}

The endometritis were maximum $(41.7 \%)$ follow by pyometra and cervicitis (25\%) and abortion $(8.3 \%)$.

Most bacteria in study were corynbacteriumpy ogens, Escherichia coli, Streptococcus, Pasteurella, Staphylococcus, Micrococcus and Pseudomonas $14(13.5 \%), 13(12.5 \%), 12(11.5 \%), 11(10.6 \%)$ and $10(9.6 \%)$ respectively.

Occurrence of other bacteria were between the range of $4(3.8 \%)$ to $8(7.7 . \%)$. In a study by Sheldon et al. (2008) and Erin et al. (2005) show that Fusobacterium spp. was largest $18(16.51 \%)$, followed by
Streptococcus spp. 17 (15.60\%), Staphylococcus spp. and Pseudomonas 16 (14.70\%), and Micrococcus spp. $14(12.84 \%)$.

Predominantly viruses during this study were Bovine herpes virus 412(46.2\%), Bovine vira ldiahearia $8(30.8 \%)$ and infectious Bovine Rhinotrachitis $6(23.1 \%)$ Bovine herpesvirus 4 (BoHV-4).

Results revealed fungus isolated was recognized as: Aspergillus spp. were the mainly important fungi $10(100 \%)$ isolated from all samples. 
Table 2: Isolation and recognition of microbesuterine samples in cattles.

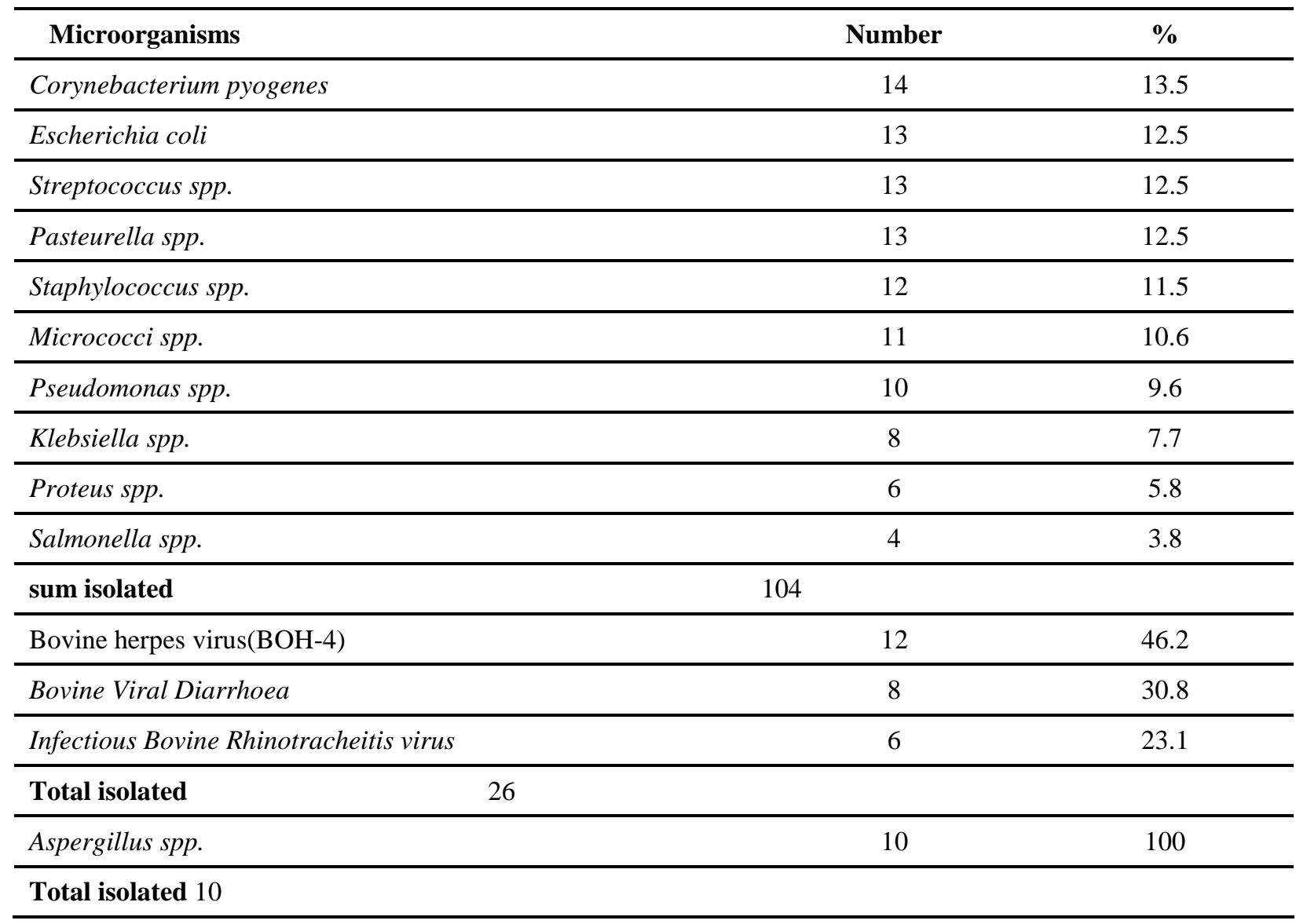

\section{DISCUSSION}

Bacteria colonizing the vagina and uterus are likely to cause reproductive failure in cow and other domestic ruminants. Vaginal bacteria get access into the uterus during the peripartum period leading to metritis and endometritis and subsequent reduction in the reproductive capacities of these animals, it is therefore important to identify these bacteria with the view of providing remedial interventions that will restore fertility (Levinson and Jawetz, 1994).

The overall frequency of endometritis during postpartam period in dairy cows may differ in different report (Gautam et al., 2009 and Ill and HyumGu 2003). Clinical endometritis is one of the most common disorders in dairy cows, causing decreased fertility and large economic loss (LeBlanc, 2008). Another very common uterine infection of cows are cervicitis and pyometra, which accounted for $25 \%$ of total reproductive disorder in this study. Other studies (Tadesse, 1999 and Oumermohammed, 2003) reported even higher percentage of pyometral cases in cows in their research. The prevalence of abortion in this study was $8.3 \%$ which is similar to the study of (Shiferaw, 1999 and Kassahun, 2003). On the other hand, (Oumermohammed, 2003; Singh and Pant, 1999) observed $3.19 \%$ and $3.2 \%$ of abortion cases in cows.
In this study, abortion found only in crossbred cows. It could be due to contamination of semen with Brucella organism during artificial insemination.

The highest numbers of organisms were found in diseased samples and most of those bacteria are pathogenic. About $60 \%$ of the identified bacteria from uterus commonly found in repeat breeders as well as from diseased animals and the frequency of the isolates were much higher than that of normal cows (Singh and Pant, 1999; Gani, 2008).

Uterine disease is commonly associated with Escherichia coli, Arcanobacterium pyogenes, Fusobacterium necrophorum and Prevotella species. Indeed, A. pyogenes, F. necrophorum, Prevotella and Streptococcus species have been shown to act synergistically to enhance the likelihood of uterine disease (Sheldon et al., 2008). In another study by Erin et al. (2005), showed that the most common and economically important bacteria for uterine infection are Actinomyces, Escherichia coli, Fusobacterium, Pasteurella, Pseudomonas and Staphylococcus. From the above discussion it is easily understood that most of the endometrial and pyogenic cases and or uterine infections were caused by Fusobacteriumspp, Actinomyces spp., E. coli, Pseudomonas spp. and Haemophilus spp. Staphylococcai spp., Streptococcus 
spp., pasteurella spp., Enterobacter spp., Klebsiella spp. and Proteus spp.

The infection viral persistently related with uterine disease after parturition in cattle (Ackermann, 2006). like to other herpes viruses, BoHV-4 can found hidden infection in animals, predominantly macrophages (Monge et al., 2006), viral infection is often known parallel bacteria cause uterine infection (Donofrio et al., 2007). So, relationship between BoHV-4 infection and uterine illness have been solid to found.

The uterine lumen was sterile before parturition. After parturition, the microorganisms inflow from the animal's environment, skin, and feces to the uterine lumen (Foldi et al., 2006). The fungi can invade tissues and cause clinical infections.4 About 100 species of fungi are generally identified as pathogens of humans and animals (Verma et al., 1999).

Aspergillus spp. were the most important fungi isolated from all samples (10 from100) According to the survey of Vlcek et al. (1989). Aspergillus spp. was reported as the most important mycobiotic agent, $43.7 \%$ (7/16), among endometritic cases in cows and buffaloes (Verma et al., 1999). Also, Aspergillus spp., Penicillium spp. and Cladosporium spp. were the highest isolated fungi from vaginal mucus of cows with complicated puerperium Vlcek et al. (1989).

\section{CONCLUSION}

This study revealed that the bacteria A. pyogenes followed by Escherichia coli, Streptococcus spp., Pasteurella spp., Staphylococcus spp., Micrococci spp. and Pseudomonas spp are more commonly isolated in clinical endometritis in cows. Clinical endometritis is the most common cause of infertility in cows and make important contribution to economic losses in the dairy industry as they delay uterine involution, prolong the time until first oestrus, increase the number of services per conception and consequently prolong the inter calving interval.

\section{ACKNOWLEDGMENT}

This research was funded by Author. More over, we would like to thank the study participants and data collectors for their fully participation and responsible data collection.

Funding: None

Conflict of interest: None declared

Ethical approval: Not required

\section{REFEREANCES}

Ackermann, M. (2006): Pathogenesis of gamma herpesvirus infections Vet. Microbiol.; 113:211-222.

Akira, S.; Uematsu, S. and Takeuchi, O. (2006): Pathogen recognition and innateimmunity. Cell; 124:783-801.

Donofrio, G.; Herath, S.; Sartori, C.; Cavirani, S. and Flammini, C.F. (2007): Bovine herpes virus 4 (BoHV-4) is tropic for bovine endometrial cells and modulates endocrine function. Reproduction 134:183-197.

Dubuc, J.T.; Duffield, K.E.; Leslie, J.S. Walton, and LeBlanc S.J. (2010a): Definitions and diagnosis of postpartum endometritis in dairy cows. J. Dairy Sci. (2010a) 93: 5225-5233.

Erin, J.W.; Debora, P.F.; Dirk, U.P. Gary, C.W. and David, E.N. (2005): Clinical evaluation of postpartum vaginal mucusreflects uterine bacterial infection and the immune response in cattle. Theriogenology. 63: 102-117.

Erin, JW.; Debora, PF.; Dirk, UP.; Gary, CWE.; David, EN.; Hilary, D. and Sheldon, IM. (2005): Clinical evaluation of postpartum vaginal mucus reflects uterine bacterial infection and the immune response in cattle. Theriogenology. 63: 102-117.

Földi, J.; Kulcsar, M. and Pecsi, A. (2006): Bacterial complications of postpartum uterine involution in cattle. Anim. Reprod. Sci., 96: 265-81.

Foldi, J.; Kulcsar, M.; Pecsi, A.; Huyghe, B. and deSa, C. (2006): Bacterial complications of postpartum uterine involution in cattle. Animal Repro Sciences, 96: 265-281

Gani, MO.; Amin, MM.; Alam, MGS.; Kayesh, MEH.; Karim, MR.; Samad, MA. and Islam, MR. (2008): Bacterial flora associated with repeat breeding and uterine infections in dairy cows. Bang J. Vet. Medicine. 6(1): 79-86.

Gautam, G.; Nakao, T.; Yusuf, M. and Koike, K. (2009): Prevalence of endometritis during the postpartum period and its impact on subsequent reproductive performance in two Japanese dairy herds. Animal Repro Sci. 116(3-4): 17587.

Gilbert, R.O.; Shin, S.T.; Guard, C.L.; Erb, H.N. and Frajblat, M. (2005): Prevalence of endometritis and its effects on reproductive performance of dairy cows. Theriogenology. 64: 1879-1888.

Herath, S.; Lilly, S.T.; Fischer, D.P.; Williams, E.J. and Dobson, H. (2009): Bacterial lip polysaccharide induces an endocrine switch from prostaglandin F2a to prostaglandin E2 in bovine endometrium Endocrinology. 150: 1912-1920.

Ill, H.K. and Hyun-Gu, K. (2003): Risk factors for post partum endometritis and the effect of endometritis on reproductive performance in dairy cows in Korea. J Repro dev., 49: 6. 
Kassahun, M. (2003): Major clinical reproductive problems of smallholder dairy cows in and around Awassa. DVM thesis. Faculty of Veterinary Medicine, Addis Ababa University, Debre Zeit, Ethiopia.

LeBlanc, S. (2007): Prevention of postpartum uterine disease. Adv. Dairy Technol. 19: 145-155.

LeBlanc, S.J. (2008): Postpartum uterine disease and dairy herdreproductive performance: A review. Vet. J. 176: 102-114.

Levinson, WE. and Jawetz, E. (1994): Medical Microbiology and Immunology. Third edition. Prentice- Hall Int. Inc., Englewood Cliffs, New Jersey-USA. Pp 20-23.

Monge, A.; Elvira, L.; Gonzalez, J.V.; Astiz, S. and Wellenberg, G.J. (2006): Bovine herpes virus 4-associated postpartum metritis in a Spanish dairy herd. Res. Vet. Sci. 80: 120-125.

Opsomer, G.; Mijtem, P.; Coryn, M. and Kruif, A.D. (1996): Post partum anoestrus in dairy cows: A Review. Vet. Quart. 18 (2): 68-75.

Oumermohammed, E. (2003): Study on major reproductive health problems of small holder diary farms in and around Kombolcha. DVM thesis. Faculty of Veterinary Medicine, Addis Ababa University, Debre Zeit, Ethiopia.

Sheldon, I.M. and Dobson, H. (2004): Postpartum uterine health in cattle. Animal Repro Sci., 8283: 295-306.

Sheldon, I.M.; Lewis, G.S.; LeBlanc, S. and Gilbert, R.O. (2006): Defining postpartum uterine disease in cattle. Theriogenology 65: 15161530.

Sheldon, IM.; Williams, EJ.; Miller, ANA.; Nash, DM. and Herath, S. (2008): Uterine diseases in cattle after parturition. Vet. J. 176(1-3): 115121.

Shiferaw, Y. (1999): Fertility status of dairy cows under different production systems in Holetta central Highland of Ethiopia. MSc Thesis, Addis Ababa University and Freie Universit at Berlin, FVM, Debre Zeit, Ethiopia.

Singh, M. and Pant, HC. (1999): Factors associated with repeat breeding in Himachal Pradesh. Indian Vet. J. 76 (6): 522-523.

Sirohi, N.S.; Monga, D.P. and Knar, S.K. (1989): Microbiological studies on some reproductive disorders of cattle. Indian J Animal Sci., 59 (5):537-541

Tadesse, M. (1999): Major post partum reproductive problems in Holetta research station and smallholders' dairy cattle. DVM thesis. Faculty of Veterinary Medicine, Addis Ababa University, Debre Zeit, Ethiopia.

Verma, S.; Katoch, RC. and Jand, SK. (1999): Mycobiotic flora of female genitalia of buffaloes and cows with reproductive disorders. Vet. Res. Commun, 23:337-41.

Vlček, Z.; Kudláč, E.; Nesňalová, E. and Láníková, A. (1989): Fertility of cows after dystocias and complicated puerperium with respect to bacteriological and mycological findings in the genitalia. Acta Veterinaria Brno 58: 245-60.

\section{تحديد مخاطر كائنات الرحم المجهرية فى الأبقار بعد الولاده فى مدينة صلاح الدين ، العراق

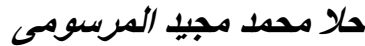 \\ E-mail address: m.hala17@yahoo.com Assiut University web-site: www.aun.edu.eg}

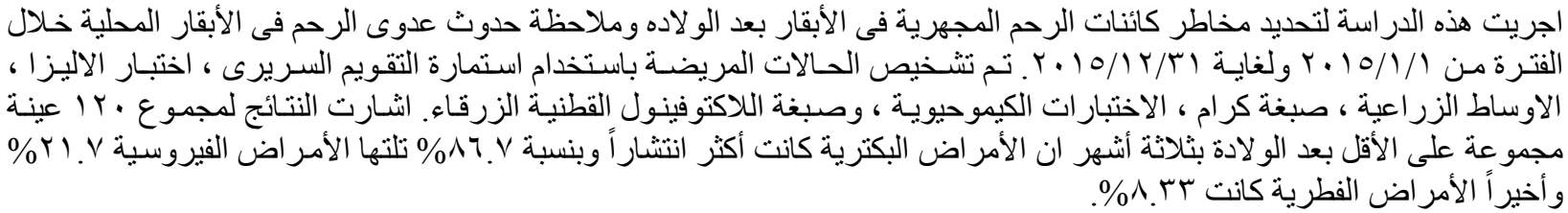

